\begin{tabular}{l|l|c}
\hline \hline Vol. 31(1):97-110 & Ocean and Polar Research & March 2009 \\
\hline \hline
\end{tabular}

\title{
Article
}

\section{수산부문 저탄소・녹색성장 패러다임}

\author{
박성쾌 $^{1} \cdot$ 권석재 $^{2^{*}}$ \\ 1부경대학교 해양산업경영학부 \\ (608-737) 부산광역시 남구 대연 3동 599-1 \\ 2한국해양연구원 해양정책연구실 \\ (425-600) 경기도 안산시 안산우체국 사서함 29
}

\section{Low Carbon - Green Growth Paradigm for Fisheries Sector}

\author{
Seong Kwae Park ${ }^{1}$ and Suk-Jae Kwon ${ }^{2 *}$ \\ ${ }^{1}$ Faculty of Marine Business and Economics \\ Pukyong National University, Busan 608-737, Korea \\ ${ }^{2}$ Policy Research Division, KORDI \\ Ansan P.O. Box 29, Seoul 425-600, Korea
}

\begin{abstract}
Two of the most important topics of the 21st century are ensuring harmony between man and his environment and the emerging long-tail economy in which niche markets are becoming increasingly more important. Since the Industrial Revolution in 17th century, human beings have increasingly exploited the world's natural capital, such as the natural environment and its ecosystems. Now the world is facing limits to sustainable economic growth because of limits to this natural capital. Thus, most countries are beginning to adopt a new development paradigm, the so-called ${ }^{\top}$ Green Development Paradigm』 which pursues environmental conservation in parallel with economic growth. Recently, the Korean government announced an ambitious national policy of Low Carbon \& Green Growth for the next six decades. This is an important step that transforms the existing national policy into a new future-oriented one. The fisheries sector in particular has great potential for making a substantial contribution to this national policy initiative. For example, the ocean itself with its sea plants and phytoplankton has an enormous capacity for fixing carbon, and its vast areas of tidal flats have a tremendous potential for cleaning up pollutants from both the sea and the land. Furthermore, the fishing industry has great potential for the development of fuel-saving biodegradable technologies, and a long-tail economy based on digital technologies can do much to promote the production and consumption of green goods and services derived from the oceans and the fisheries. In order for this potential to be realized, the fisheries authority needs to develop a new green-growth strategy that is practical and widely supported by fishing communities and the markets, taking into account the need for greenhouse gas reduction, conservation of the ocean environment and ecosystems, an improved system for seafood safety, the establishment of strengthened MCS (monitoring·control-surveillance) system, and the development of coastal ecotourism. In addition, fisheries green policies need to be implemented through a well-organized system of government aids, regulations and compensation, and spontaneous (voluntary) orders in fishing communities should be promoted to encourage far more responsible fisheries.
\end{abstract}

Key words : harmony, green growth, long tail economy, natural capital, EBFM

\footnotetext{
*Corresponding author. E-mail : sjkwon@kordi.re.kr
} 


\section{1. 서 론}

최근 세계적으로 확산되고 있는 저탄소 - 녹색성장 이 슈는 인류 문명사에 있어서 필연적인 결과다. 17세기 산 업혁명 이후 인류가 지향해온 발전패러다임은 자연환경을 무차별하게 개발 - 이용하는 것이었다. 그 과정에서 과학 과 기술의 만남은 자연환경의 개발영역을 크게 확대시켰 고 개발속도를 급진전시켰다. 그 결과 오늘날 세계는 눈부 신 발전의 이면에 드리워진 그림자의 실체를 발견하게 되 었다.

그 그림자의 실체는 20 세기 중반까지만 해도 뚜렷하게 부각되지 않았고, 1960년대 초 R. Carson의『조용한 봄 (Silent Spring)』이 세상에 출간되었을 때야 비로소 미국 을 비롯한 주요 공업국들은 환경오염의 심각성에 경악을 금하지 못했다. 그 후 1986년 한국공해문제연구소가 우리 나라의 공해문제를 고발하는 『한국의 공해지도』를 출 간하면서, 우리 사회는 공업화의 이면에 가려졌던 환경문 제에 관심을 가지기 시작했다.

한국의 공해지도가 출간된 지 30 년이 지난 오늘! 우리 사회는 저탄소·녹색성장이라는 환경친화적 성장 패러다 임을 국가정책의 핵심정책으로 채택하게 되었다. 이는 소 위 환경쿠츠네츠 곡선(Environmental Kuznets Curve: $\mathrm{EKC}$ )이 시사하는 현상이라고 할 수 있다. $\mathrm{EKC}$ 는 경제개 발 초기 경제가 성장할수록 환경오염 수준이 증가하다가 어느 수준을 넘어서면 소득이 증가할수록 환경오염 수준 이 감소한다는 것을 실증적으로 나타낸 완만한 역 U자 형 의 곡선을 말한다. 이런 관점에서 볼 때, 이제 우리나라도 환경보전에 높은 가치를 부여할 정도로 국민 1 인당 소득 수준이 높아졌다는 것을 의미한다.

이를 정책 철학적 관점에서 보면, 우리 사회구성원들은 부분과 전체의 딜레마를 인식하기 시작했고, 나무만을 보 고 달려온 경주를 잠시 멈추고 숲을 바라다 볼 수 있는 여유를 가지게 되었음을 의미한다. 우리는 비로소 이제 우리의 삶을 총체적으로 지배하는 자연환경이라는 숲이 우리의 생존에 얼마나 중요한가를 새삼 깨닫게 된 것이 다. 저탄소 - 녹색성장이 파괴된 자연환경을 복구 - 유지 하면서 동시에 경제성장을 실현해가는 것이라면, 중요한 것은 환경의 복구와 유지에 수반되는 비용이 얼마나 높을 지 현재로선 가늠하기 어렵지만 매우 클 것으로 예상된다 는 것이다.

그럼에도 불구하고, 아직도 사회적 갈등이 상존하지만, 해양을 포함한 전반적 자연환경 복구에 대한 원론적 사회 적 합의는 이미 이루어졌고, 그에 대한 국가적 비전과 전 략도 수립되었다. 국가 비전과 전략이 구체적이고 연계된 부문별 정책으로 추진되기 위해서는 그와 연계하여 부문 별·지역별 비전과 전략이 수립·추진되어야 한다. 자연
환경과 생태계는 유기적으로 상호 연계되어 하나의 가이 아(Gaia)를 형성하고 있듯이, 녹색성장정책도 생태계처럼 하나로 연계·통합된 유기체적 시스템을 갖추어야 할 것 이다.

이와 관련하여, 우리는 '하이젠베르크의 부분과 전체', '화이트헤드의 옥망을 절제할 수 있는 욕망', '하이에크의 자생적 질서'의 철학적 시사점을 충분히 음미해봐야 한다. 이들의 철학적 시사점은 새로운 성장정책에 대한 인식이 어떻게 어떤 방향으로 전화되어야 할 것인가에 대한 해답 을 줄 수 있다. 이 해답이 중요한 이유는 정책의 성공은 구호가 아닌, 사회구성들의 변화된 인식으로부터 진정한 지지를 이끌어낼 수 있기 때문이다. 사실, 정책은 분명히 선택의 문제이지만, 그 성공은 국민적 지지에 달려있고 따라서 협력적 지지의 확보를 위해서는 최선의 선택 보다 는 차선 또는 차 차선의 선택을 불가피하게 하는 경향이 있다.

이상의 관점에서 본 연구는 21 세기 화두를 중심으로 환 경에 대한 새롭고 거시적인 주요 인식의 변화를 분석하고, 자연자본이론에 입각한 녹색성장의 이론적 배경을 고찰하 고, 국가 저탄소 - 녹색정책을 토대로 수산부문의 저탄소 녹색성장 패러다임을 제시하는데 주된 목적을 두고 수행되 었다.

\section{2. 새로운 인식의 출발}

\section{1세기의 화두}

21세기의 화두! 거기에는 수많은 담론이 있을 수 있다. 그러나 많은 사람들은 김용옥 교수(1999)가 말하는 세 가 지 21세기 글로벌 화두에 동의할 것이다. 첫째가 인간과 자연환경의 화해이고, 둘째는 지식과 삶의 화해이며, 셋째 는 종교와 종교 간의 화해라고 할 수 있다. 이 중 첫 번째 와 두 번째 화두는 곧 21 세기 인간과 바다의 화해라고도 할 수 있다.

21 세기 인류의 가장 중요한 화두는 '인간과 자연환경의 화해' 또는 '인간과 바다의 화해'라고 해도 과언이 아니 다. 사실, 바다는 지구표면의 $71 \%$ 를 덮고 있으며, 수산업 은 바다산업이기 때문이다. 수산업은 농업과 마찬가지로 자연(해양)환경에 전적으로 의존하는 산업이고 동시에 자 연 순응적 산업이다. 그러나 자세히 살펴보면 어업과 농업 사이에는 유의한 차이점이 있다는 사실을 쉽게 발견하게 된다. 첫 번째 차이점은 '물고기는 자연(自然)이 기르지 만, 농작물은 사람(人)이 재배한다'는 점이다. 물고기 양식 기술이 발전함에 따라 최근 상당량의 양식생산이 이루어 지고 있지만, 바다가 스스로 낳고 기르는 물고기의 양이나 종류에 비하면 인간의 기술적 능력으로 바다 생물을 가꾼 다는 것은 거의 불가능에 가까운 일이다. 
두 번째 차이점은 '농업이 토지의 사적 재산권을 기반 으로 성립하는 반면, 어업은 주인 없는 물고기, 즉 수많은 사람들이 공동으로 이용하는 공유자원을 근간으로 성립한 다'는 점이다. 따라서 토지는 단일 경작자에 의한 배타적 이용과 관리가 가능한 반면, 물고기 자원은 수많은 사람들 에 의하여 이용되고 관리되기 때문에 공적관리가 필수적 이라는 측면에서 사적 토지 관리를 기반으로 하는 농업과 큰 차이가 있다. 세 번째 차이점은 '물고기는 해양 생태계 의 먹이 피라미드를 통하여 스스로 재생산하는 자연 자가 갱생자원이기 때문에 생산과정에서 농작물의 재배처럼 엄 청난 양의 노동과 비료, 맹독성 농약과 같은 화학물질을 필요로 하지 않다'는 점이다. 따라서 바다 생태환경을 건 강하게 보존하고, 자가 갱생이 충분히 가능할 정도로 어획 노력수준과 어획량을 조절할 수 있다면 농업처럼 막대한 양의 노동과 비료 그리고 농약을 사용하지 않고도 세계는 무공해 단백질 식량인 물고기를 매년 1 억 톤 이상을 영속 적으로 건져 올릴 수 있다는 것이다.

바다의 이 거대한 잠재력은 바로 1차 생산력(식물성 플 랑크톤 생산력)을 기반으로 자연(自然) 속에 정교하게 설 계된 먹이그물 시스템에 있다. 아무런 생산요소를 투입하 지 않고도 매년 1억 톤 이상의 물고기를 생산할 수 있다 는 사실은 참으로 놀라운 사실이다. 그러나 불행하게도 우 리는 바다의 속성과 거대한 생태계를 충분히 이해하기 전 에 이미 그 잠재력을 능가할 정도의 어획기술을 발전시킴 으로써 자연(바다)의 정교한 생태계와 그 역동적 과정을 손상시키고 있다. 21세기 초에 들어서서야 비로소 인류는 이 거대한 바다환경과의 화해가 인류 생존과 번영에 매우 중요하다는 사실을 인식하고 있다.

또 하나의 중요한 화두는 '지식과 삶의 화해'다. 이는 노자철학(老子哲學) 전반을 관통하는 반주지주의적 사상 과 깊은 관련이 있다. 지식은 본래 삶에서 나왔고, 삶을 위 한 것이라는 데는 의문의 여지가 없다. 그런데 지식 그 자 체가 삶을 위협하고, 삶을 노예화하고, 삶을 괴롭히고 있 다는데 심각한 문제가 있다. 오늘날 우리는 '궁극적으로 지식체계가 과연 우리의 삶에 무엇을 의미 하는가'라는 매우 근원적인 질문을 우리 스스로에게 던지고 있다.

인류의 지식체계와 과학기술체계는 두 가지 큰 방향으 로 발전해왔다. 하나는 자연에 내재되어 있는 질서를 발견 하는 것(예: 만유인력의 법칙, 케플러 법칙, 양자역학 등) 이고, 다른 하나는 자연을 정복하고 이용하기 위한 것(예: 거대한 공장형 트롤선, 산림 벌채 기술, 맹독성 화학물질, 유전공학 등)이었다. 환언하면, 전자는 순응적 질서를 탐 구하는 것이고, 후자는 인공질서를 모색하는 것이다. 그러 나 우리는 물고기를 탐색하고 잡는 기술을 개발하는 과정 에서 바다 자체와 바다가 물고기를 키우는 질서를 이해하 기 위한 노력을 소홀히 해왔다. 그 결과 바다가 중병에 걸
려 신음하고 있다는 사실을 인지한 후에야 겨우 바다생태 환경을 이해하기 위한 노력을 기울이기 시작했다.

17세기 산업혁명 이후 이루어진 과학과 기술의 랑데부! 그것은 순식간에 우리가 살고 있는 문명의 모습을 통째로 바꾸어 놓았다. 자연환경 파괴의 대가로 얻은 과학기술의 성과는 육지와 바다 그리고 우주에서 놀라운 진보를 가져 왔다. 과학기술의 진보는 우리의 과학적 사유 영역을 놀라 울 정도로 크게 넓혀주었다. 보이지 않던 것이 보이게 되 었고, 개발의 영역이 아니던 것이 개발될 수 있게 되고, 인 간사유의 대상조차 아니었던 것들이 사유의 영역 안으로 들어왔다. 공상이 현실로 변모해갔던 것이다. 꿈이 현실로 된다는 것은 매우 즐겁고 기쁜 것이다. 그러나 우리는 이 기쁨에 도취한 나머지 지식과 삶의 조화가 우리의 지속가 능한 생존에 필수적 이라는 사실을 망각하였다. 우리는 부 지불식간에 꿈 자체를 하나 둘 잃어가고 있었던 것이다. 많은 꿈을 상실한 후, 이제야 우리는 자연환경(바다환경) 관리와 이용 사이의 균형이 긴요하다는 사실을 새롭게 인 식해가고 있다.

\section{상보성(相補性 Complementarity)에 대한 새로운 인식}

부분과 전체의 딜레마! 즉, 나무와 숲을 동시에 볼 수 없고, 미시세계와 거시세계를 동시에 볼 수 없는 상보성의 원리는 우리 인간에게 주어진 근본적인 한계다. 인간의 속 성 중 하나는 미래보다는 현재를 중시하고, 넓고 멀리 보 기보다는 근시안적으로 보는 경향이 있으며, 공익보다 사 익을 중시하고, 장기적 이익추구보다는 단기적 이익추구 를 중시한다는 것이다. 이러한 인간의 속성은 바로 인간의 내재적 한계인 상보성에 기인한다.

지난 반세기 동안 우리는 해양환경과 생물자원의 균형 적 이용을 위한 노력을 끊임이 기울여왔다. 그에 대한 정 책 슬로건이나 키워드는 자원보존, 자원회복, 지속가능한 수산업발전 등이었다. 그런 슬로건 또는 캠페인이 끊임없 이 대두되고 이루어져 왔음에도 불구하고, 왜 해양생물자 원은 긇임없이 남획과 멸종의 위기에 직면하고 있는 것인 가? 이는 참으로 아이러니가 아닐 수 없다. 그 아이러니에 대한 단서가 쉽게 발견될 것 같지만, 사실은 그렇지 않다. 왜냐하면 그것은 인간이 부분과 전체를 동시에 볼 수 없 는 양자론적(量子論的) 법칙에 가려져 있기 때문이다.

만일 과잉어획노력이 문제의 본질이라면, 어선 감척사 업을 통해 어획강도를 지속적으로 줄이고 있음에도 불구 하고 왜 유효어획강도는 줄지 않고 아직도 여전히 문제가 되고 있는 것인가? 그에 대한 근본적인 원인은 어업사회 의 임금 시스템에서 찾을 수 있다. 사실 임금제도는 인간 의 사고와 행동을 특정 방향으로 유인하는 가장 중요하고 강력한 경제적 인센티브(incentives)이고 동시에 디스인센 티브(disincentives)이기도 하다. 우리나라 어업에는 보합 
제도라고 하는 임금 또는 분배 제도가 존재한다. 보합제도 란 공동어업경비를 제하고 나머지를 선주와 선원들이 합 의된 비율로 분배하는 보수체계다. 이 경우, 양자(兩者)는 보다 많은 보수를 얻기 위해 협력적으로 최선을 다 하게 된다. 환언하면, 선주는 어군 탐지기 등 최신 어로 장비를 제공하는 반면, 선원들은 그것을 이용하여 어획량을 극대 화하고 어업경비를 최소화하기 위한 강한 동기를 가지게 된다. 감시 · 통제 - 감독, 즉 $\mathrm{MCS}$ (monitoring - control · surveillance) 시스템이 원활하게 작동하지 않는 상태에서 수산물 가격이 생산비를 초과하는 한, 보합제라고 하는 임 금 시스템은 생산량 - 어획노력 극대화를 유인하게 된다. 따라서 MCS 시스템의 설계가 아무리 정교하다고 할지라 도, 그 집행력이 낮고 엄격하지 않으면 어업인들은 $\mathrm{MCS}$ 를 회피하기 위한 아주 정교하고 새로운 전략과 기술을 개발 · 구사하게 된다.

남획과 불법행위 그리고 도덕적 해이 문제를 완화하기 위하여 보완적으로 고안된 것이 바로 옵서버제도(observer program: OP)를 수반하는 총 허용어획량(total allowable catch: TAC)제도 라고 할 수 있다. 그러나 $\mathrm{TAC}+\mathrm{OP}$ 제도 는 효율성에 비해 상대적으로 높은 비용을 수반하고 어업 사회는 기꺼이 그것을 수용하려고 하지 않을 뿐만 아니라 국가 정책사업의 우선순위에서 상대적으로 낮은 위치를 점하고 있다. 또한 투입·산출효과가 뚜렷하지 않고 정치 적 지지도도 낮다. 따라서 예산당국은 막대한 비용조달에 소극적인 경향를 보이는 것이다. 여기에 바로 수산자원 관 리정책의 딜레마가 존재하고, 결국 다양한 자원관리정책 은 부분적이며 통합성을 가지지 못한 채 시행됨으로써, 기 대되는 효과(목표)를 실현하지 못하는 것이다.

또 하나의 자원관리정책의 한계는 영세성(특히 연안어 업)이라는 우리나라 어업구조의 특성에 있다. 산업 간·산 업 내의 불평등지수가 높으면, 환경 및 자원에 대한 보존 과 이용의 조화가 현실적으로 어렵다. 왜냐하면 어떤 사회 를 막론하고 그 구성원들의 소득 수준이 일정 수준에 이 르기 전까지는 개발에 대한 옥구가 환경보존에 대한 욕구 를 크게 압도하기 때문이다. 정책입안자들과 MCS 당국 (예: 어업지도선, 해양경찰 등) 또한 그것이 정치적으로 민 감한 사안일 뿐만 아니라 그에 대한 사회복지 차원의 정 책이 필요하다는데 이의를 제기하지 않는다. 따라서 다수 의 영세어업과 생계형어업이 존재하고 그들에 대한 특단 의 대책이 강구되지 않는 한, 자원남획과 불법어업행위는 지속될 수밖에 없을 것이다. 이러한 문제는 연안어업과 근 해어업, 영세어업과 생계형 어업의 구분이 부재한데서 비 롯되고 있으며 수산정책의 대상과 목표를 모호하게 만드 는 경향이 있다.

그러나 다행스럽게도, 연근해 어업자원이 지속적으로 감퇴하고 수산물 시장이 개방됨에 따라 최근 어업사회는
대량생산을 지양하고, 자원 보존과 이용 간 조화, 국내산 외국산 수산물 차별화, 가치제고를 중시해야 한다는 새로 운 현실을 인식하기 시작했다. 이제 우리 수산사회는 수산 업을 보다 넓은 시각에서 보게 된 것이다. 또한 저탄소. 녹색 수산업 발전의 관점에서 볼 때, 이른바 자율관리어업 은 능동적 어업(자원)관리 질서의 창출을 위한 매우 중요 한 시작이라고 할 수 있다. 뿐만 아니라 세계적으로 주목 받고 있는 '생태계를 기반으로 하는 자원관리(ecosystembased fisheries management: EBFM)'에 대한 인식도 점차 높아지고 있는데, 사실 $\mathrm{EBFM}$ 은 통합되고 연계된 해양생 태계에 대한 새로운 인식의 출발이라고 할 수 있다. 이는 부분적 인식이 전체적 인식으로 전환되는 매우 의미 있는 현상이며, 인공질서의 한계를 자생적 질서에 의해 전체론 적 관점에서 극복하고자 하는 수산사회의 자각이라고 할 수 있다.

\section{롱테일 경제(Long Tail Economy)의 출현과 확산}

롱테일이란 시장을 왜곡시켰던 장애물들이 제거되고 무 한한 선택이 가능해짐에 따라 수요곡선의 꼬리부분이 머 리 부분보다 길어져 그 동안 무시되었던 틈새시장(niche markets)이 중요해지고 있는 디지털 시대의 새로운 경제 패러다임을 말한다(Fig. 1). 틈새상품의 경우, 각각의 매출 액은 적지만 그것들의 총합은 히트상품과 맞먹거나 오히 려 능가하게 된다(앤더슨 2006). 인터넷의 등장으로 소수 의 히트상품 $(20 \%)$ 이 매출액의 $80 \%$ 를 만들어낸다는 $80 /$ 20 법칙 또는 파레토(Pareto)법칙으로는 더 이상 설명될 수 없는 새로운 경제현상이 나타나고 있다. 히트상품이 아닌 롱테일(long tail)에 있는 무수히 많은 틈새상품들이 수익 을 만들어널 21세기에는 과거처럼 히트상품에만 매달리면 많은 시장 기회를 잃게 될 것이다.

기존의 $80 / 20$ 이론은 어떤 상점에 전시된 상품이 100 가 지가 있다고 가정할 때 그 중 잘 팔리는 20 가지의 상품이 그 상점 수익의 대부분을 차지하게 된다는 이론이다. 그렇

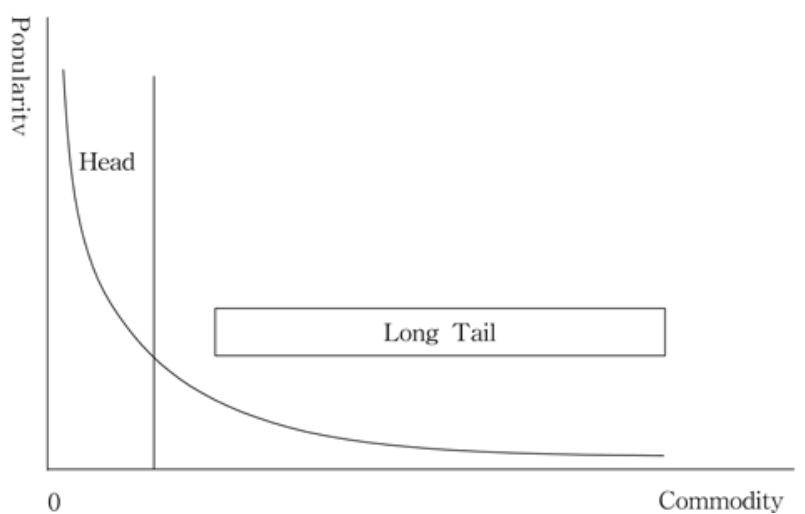

Fig. 1. Relationship between commodity and popularity (Head vs. Long Tail). 
다면 나머지 80 가지의 상품은 인기가 없고 찾는 사람도 별로 없는 그런 상품들이다. 경제·사회 전반적으로 실제 상위 $20 \%$ 의 무엇인가가 전체를 움직이는 경향은 현실 세 계에 분명히 존재한다. 그러나 디지털시대가 도래하면서 최근 나머지 인기는 없지만 개성 있는 $80 \%$ 의 잠재적인 재화나 서비스의 거래가 중요시되고, 이에 대한 많은 논의 가 활발하게 이루어져 왔다.

그 논의과정에서 탄생된 롱테일 경제이론은 그 동안 잊혀졌던 $80 \%$ 에 대한 이론이다. 그렇다면 잊혀졌던 $80 \%$ 를 어떻게 찾을 수 있을까? 그 해답은 바로 정보기술 (information technology: IT)의 발전에서 얻어질 수 있다. 롱테일 현상은 현재와 같이 IT를 기반으로 하는 인터넷이 확산 - 정착되기 이전에는 상상도 못했던 것이다. 그러나 중요한 것은 잘 팔리지 않고 인기 없는 $80 \%$ 의 재화나 서 비스일지라도 누군가는 그것을 필요로 한다는 사실이다. 과거에는 그것을 탐색하는데 많은 시간과 비용을 지불해 야 했다. 그러나 지금은 사이버 공간에서 내가 찾는 물건 이 어디에 있고, 얼마나 하며, 어떻게 구입하고, 배달기간 이 어느 정도 소요되는지에 대한 모든 정보가 비교 가능 할 수 있도록 총 망라되어 있다.

IT의 눈부신 발전은 새로운 유통혁명을 일으키고 있으 며 진열공간과 거래비용(예: 유통마진 등)의 한계를 단숨 에 극복할 수 있는 수단을 제공하고 있다. 생산수단과 유 통구조의 대중화를 통해 그야말로 프로슈머(prosumer)의 시대가 도래하고 있는 것이다. 이는 21 세기 첨단과학과 첨단기술의 랑데부가 만들어내고 있는 전혀 새로운 롱테 일 경제 패러다임이자, 개성이 뚜렷한 개미들의 경제세계 다. 틈새시장이 중요시되는 롱테일 경제 하에서는 특징 있 는 상품에 대해 충성도가 높은 고객을 확보 - 확대할 수 있고, 고객 중심의 거래방식을 현실화할 수 있는 수단이 가용하게 된 것이다.

가치와 개성 그리고 개미들이 중요시되는 21 세기! 정보 화의 진전은 틈새시장과 거대시장의 공존을 가능하게 하 고 있다. 그런가 하면, 지방-지역적인 것(예: 지역 특산 품, 지역 관광, 지역 문화유산 등)이 세계적인 것으로 되 어가고, 그 속도 또한 놀라울 정도로 빨라지면서 글로컬라 이제이션(glocalization)의 시대가 열리고 있는 것이다. 지 금처럼 국경조치가 급격히 완화 또는 철폐됨으로써 세계 화가 급격히 진전된다면, IT의 발전은 한편으로는 분산된 경제권을 단일 지구촌 경제권으로 만들어가고, 다른 한편 으로는 기존 거래의 점점 더 많은 부분을 사이버 공간으 로 옮겨 놓게 될 것이다. 사이버 공간에서의 거래가 증가 하면 할수록, 특히 식품의 경우, 상품에 대한 보증과 안전 성에 대한 소비자의 관심이 높아지고, 그로 인한 추가적 가격 상승에 대한 소비자의 지불의사도 높아지게 될 것 이다.

\section{자생적 질서의 확산}

상보성(相補性)에 의해 주어진 인간의 한계를 극복하고 '자연환경과 인간의 조화'와 '지식과 삶의 조화'를 실현하 기 위해 인간은 스스로 질서를 만들어 운영해오고 있다. 인류가 만들어낸 질서에는 Hayek(1973)의 두 가지 질서, 이른바 자생질서(spontaneous orders)와 인공질서를 들 수 있다. 자생적 질서는 외부의 간섭이 없어도 창출되고 유지 되는 문화적 진화의 산물인 반면, 인공질서란 특정 집단이 나 조직이 어떤 목적을 실현하기 위하여 만든 강제되는 질서다.

전자는 화이트헤드(2000)가 말하는 인간 내면에 존재 하는 '욕망을 절제할 수 있는 욕망(the appetition of appetitions)'을 전제로 하는 능동적 질서이고, 인간의 자유 를 지속적으로 확대하는 질서다. 반면, 후자는 수동적 질 서이자 인간의 자유를 끊임없이 유보하고자 하는 오늘날 의 질서법과 제도이다. 현재 우리 수산사회에서 나타나고 있는 자율어업관리 질서는 바로 자생적 질서의 한 형태이 며, 이는 수산업법을 포함한 수많은 수산 관련 법제도(인 공질서)가 바람직한 어업(자원)관리에 한계가 있음을 보여 주는 좋은 사례다.

인공질서가 기대되는 결과를 실현하기 위해서는 정교하 게 설계되어야 할 뿐만 아니라 동태적으로 변화하고 조정 될 수 있는 유기체적 시스템의 구조를 지녀야 한다. 그렇 지 않으면, 특정 목적을 달성하기 위하여 인위적으로 질서 를 만들고 운영하는 조직이나 사람들은 현실 세계에서 일 어나는 변화의 인과(因果)에 대한 정보를 충분히 확보할 수 있는 능력을 갖추어야 한다. 그러나 그것이 가능한 일 이겠는가? 또한 법제도를 바꾸기 위해서는 흔히 상당한 시간을 요하는 정치적 과정을 거쳐야 한다. 정부간섭의 당 위성이 인정된다고 하더라도, 그러한 인공질서의 한계는 광범위한 정보가 동태적이고 능동적으로 집적되고 확산되 는 자율적 · 자생적 절서의 창출을 필요로 한다.

특히 기후변화 또는 지구온난화는 장기간에 걸쳐 진행 되기 때문에 바다와 연안지역 생태 환경 변화와 함께 살 아온 어업인들은 과학적이지는 아닐지라도 체험적으로 미 시적 거시적 해양생태계의 질서변화를 이해하고 있다. 그 런 변화에 대한 오랜 경험을 통해 그들은 기후변화와 자 연 질서에 순응하는 지혜를 터득해왔다. 이런 자연 질서의 변화를 충분히 고려하지 않은 강제되는 질서가 지속적으 로 만들어지고 유지된다면, 수산사회는 그런 현실과 괴리 를 보이는 인공질서를 수용하는데 주저하게 될 것이다. 따 라서 인공질서가 양산될수록 현실과 법제도 사이에는 점 점 더 큰 격차가 발생하고, 그 격차는 결국 현실적으로 큰 사회적 갈등과 비용을 초래할 가능성이 높아진다.

여기서 우리는 자원관리의 개념에 대한 중요한 철학적 문제를 제기할 수 있다. 노자의 자연관에 따르면 자연(自 
然)은 스스로 그러하다. 자연의 일부인 물고기도 스스로 그러 할진데, 그렇다면 누가 관리의 대상이 되어야 하는 가? 그 대상은 분명히 이용자(즉, 사람)다. 그렇다면, 정 책적 어휘가 분명해지기 위해서는 '자원관리(resource management)'라는 말은 '이용자(사람)관리(user·people management)'라는 말로 대체되어야 할 것이다. 왜냐하면 물고기라는 자연자본은 당사자 권리가 없는 반면, ${ }^{1)}$ 사람 에게는 그 권리가 있기 때문이다. 또한 관리의 대상이 분 명하면, 관리제도의 변화와 정책의 목표 및 방향도 뚜렷해 지고, 정책의 우선순위도 자연스럽게 결정될 수 있기 때문 이다.

\section{3. 저탄소・녹색성장의 이론적 배경}

\section{자연자본의 개념과 역할 자연자본의 개념}

자연자본(natural capital)이란 인위적 생산수단(예: 기계, 연장, 시설, 건물 등)으로 정의되는 자본에 대해 전통적인 경제학적 개념의 확장된 개념이다. 자연자본과 인공자본 의 공통점은 가치 있는 재화와 서비스의 유량(flow)을 생 산하는 스톡(stock)으로서, 그 두 개념 모두 실제로 이용되 는 자본의 개념이다. 어업자원 스톡은 새로운 물고기의 형 태로 재화의 유량을 생산하며, 그 유량은 가치로 환산될 수 있다. 또한 스톡을 소진한다는 것은 곧 자본의 소비라 고 할 수 있다.

자연자본은 크게 두 가지 종류, 즉 갱생 자연자본 및 소 진(비갱생) 자연자본과 하이브리드(hybrid) 자연자본으로 나눌 수 있다. 갱생 자연자본은 주로 살아있을 뿐만 아니 라 능동적이며, 생태계는 주로 갱생 자연자본으로 구성되 어 있다. 그것에 충격이 가해지지 않는 경우, 갱생 자연자
본은 탄소동화작용을 통해 태양 에너지를 식물 개체군으 로 전환하고 궁극적으로는 먹이망(food web)으로 전환함 으로써 영속적으로 유지되고 그 자체를 재생산한다. 손상 되지 않고 햇빛이 있는 한, 자연자본은 유용한 재화와 서 비스의 유량을 영속적으로 생산하게 된다. 그런 의미에서 갱생 자연자본은 무한한 것처럼 보이지만, 그 유량의 규모 는 사실상 유한하다. 따라서 갱생 자연자본이 과도하게 이 용될 경우, 그 자체의 재생산 능력과 우리의 의존도가 높 은 재화의 유량을 유지할 수 있는 능력이 손상될 수 있다. 다른 한편으로, 소진자연자원(예: 대부분 석탄연료와 광 물)은 비갱생적 특징을 지닌다. 소진자연자본의 스톡은 유 한하지만 유량율은 우리의 선택과 정책에 달려있다. 땅 속 에는 많은 기름이 부존하지만 우리의 선택에 의해 그것을 단기간에 또는 장기적으로 퍼 올릴 수 있다. 소진자연자본 은 채굴되어 유용한 형태로 전환되기 전에는 전혀 서비스 를 생산하지 못하는 속성을 지니고 있다(Costanza and Daly 1992).

하이브리드 자연자본은 자연자본과 인공자본이 결합된 자본의 개념이다(Daly 1991). 이는 물고기 양식장, 나무농 장, 잔디농장, 온실종묘장과 같은 모든 물고기 양식·재배 시스템을 포함한다. 이들 시스템의 구성요소들은 모두 인 위적인 것은 아니지만, 그렇다고 완전히 자연적인 것만도 아니다. 인간은 자연자본의 일부 요소를 이용하고 선택육 종, 단종재배와 같은 방법을 통하여 자연자본이 기능하는 방식을 바꿈으로써 인공자연자본(cultivated natural capital) 을 창출한다. 예컨대 물고기 양식은 자연자본의 연장선상 에 있지만, 높은 수준의 인공자본이 가미된 것이다.

인공자본과 자연자본 그리고 인공자연자본 외에도 인적 자본(human capital)이 있다. 인공자본처럼 인적자본은 사 람으로부터 유래되고, 인간의 지식, 기술, 문화의 집합체

\footnotetext{
1) 「자연의 당사자 권리 이론」은 자연의 고유한 가치, 보호자의 결여, 공공의 요구 등을 논거로 그 권리 및 권리주체성을 주장해 온「자연의 권리」소송론에 그 근원을 두고 있다. 그 원조인 Stone(1972)은 인간뿐 아니라 국가나 법인, 학교, 선박 등과 같은 비 인격체들도 권리의 주체가 될 수 있는 것처럼 자연(물)도 법적 권리를 보유할 수 있고, 그 권리가 침해되면 방해배제, 원상회복, 손 해배상을 받을 수 있도록 해야 하며, 다만 자연(물)의 권리는 그 권리를 가장 잘 보호할 수 있는 사람(또는 단체)이 대리하거나 대 위하여 행사할 수 있다고 주장했다. 이러한 주장은 머지않아 이론과 실무 양면에서 적지 않은 반향을 불러 일으켰으나, 스톤 교수 자신이 저서 출간 25 년이 지난 후 지적하고 있듯 비인격체에게 당사자적격을 인정하자는 주장에 대한 비판도 적지 않았다. 그러 나 스톤의 주장은 다음에 보는 일련의 소송들을 촉발시키는 계기가 되었을 뿐 아니라 독일이나 일본 등 다른 나라에까지도 동조 자들을 넓혀 나갈 수 있었다. 독일의 경우, 압도적인 통설은 판례와 함께 자연물의 권리주체론을 부정한다. 그러나 자연의 법적 주 체성을 인정해야 한 인간과 자연간의 균형을 회복할 수 있다고 역설하는 견해를 위시해 미국의 스톤 교수의 영향을 받아 자연의 고유한 권리를 인정하려는 학설이 나타나기 시작했다. 라임바흐어(Jorg Leimbacher) 같은 학자는 자연의 권리를 인정함으로써 환 경파괴의 결정적 요인이 되는 현행법질서의 근본적인 구조적 결함, 즉 인간중심적 사고를 극복할 수 있으며, 환경은 신앙이나 양 심의 자유, 영업의 자유나 언론의 자유 같은 것은 필요로 하지 않겠지만, 적어도 위협받고 따라서 우선적으로 보호되어야 할 현재 상태에서의 존재에 대한 권리, 즉 생존기본권은 반드시 보장되어야 한다고 주장한 바 있다. 한편, 최근까지 일부 주법 차원에서 인 정되었지만 활발히 이용되지 못했던 이타적 단체소송, 즉 단체들이 비단 협의권 침해라는 주관적 이유뿐만 아니라 객관적 자연보 호법령위반을 이유로 제기할 수 있는 단체소송이 오루후스협정(Aarhus-Konvention)의 요청에 부응한다는 취지에서 연방자연보호 법에 도입되었다. 한편 일본의 경우에도 일본 환경법률가연맹의 후지와라 다케지(藤原猛爾) 변호사 등이 중심이 되어 「자연의 권리」 소송론을 발전시켜 왔고 그 결과 아마미 흑토끼 소송으로 이어질 수 있었다.
} 
로 정의할 수 있다. 인적자본은 인간이 자연환경에 반응하 고 순응하는 방법을 제공할 뿐만 아니라 인간 자신의 목 적을 위하여 그것을 변화시킬 수 있다. 인적자본은 또한 인간이 자연세계에 대하여 무엇을 해야 하고, 무엇을 하지 말아야 하는지를 판단하는 자연세계에 대한 인간의 관점 과 윤리 시스템을 포함한다. 또한 인간의 윤리 시스템의 기반이 되는 철학과 우주관 그리고 자연세계에 대한 인간 의 행동을 관리하기 위해 구축된 법제도도 중요하다. 그 외에도 인적자본에는 과학적으로 축적된 데이터와 이론, 환경과 그 기능에 대한 개별적이며 전통적인 지식이 포함 된다(Berkes and Folks 1994).

\section{자연자본의 역할}

자연자본이 수행하는 다양한 역할은 크게 두 가지 방법 으로 분류할 수 있다. 하나는 자연자산의 관점에서 분류하 는 것이고 다른 하나는 직·간접 경제적 가치의 관점에서 분류하는 것이다. 분류방법에 관계없이, 자연자본을 단순 히 자연자산으로 인식하는 것은 그것의 역할과 기능을 심 각하게 왜곡하는 것이다. 자연자본의 가장 중요한 가치는 생명유지 기능에 있다. 나머지는 부차적인 것이라고 할 수 있다. 생명유지 시스템으로서 자연자본은 생물·물리적으 로 생명유지에 필수불가결한 식량, 에너지, 미네랄, 공기, 물 등을 제공하는 유기체와 프로세스 그리고 자원으로 구 성되어 있다.

지방 - 지역 · 글로벌 차원에서, 생태계의 기능성은 궁 극적으로 그것의 통합성과 생물종간 복잡한 상호연결망의 완전성에 있으며, 그 통합성과 연결망은 동태적으로 작동 하고 유지된다. 또한 생태계의 동태성은 그것의 통합성과 연결망의 복잡한 내재적 속성이기 때문에 생물다양성(생 물종의 수와 분포 그리고 동태적 상호작용)은 생명유지를 위한 자연자본의 가장 중요한 가치이고, 자연자본의 이용
은 필연적으로 생태계의 동태성을 교란시키게 된다. 예컨 대, 살아 움직이는 생태계는 마치 회전의(回轉儀)와 같아 서 움직이는 회전의에 손을 댈 경우, 그것은 균형을 잃고 흔들 릴 수밖에 없다. 일단의 과학자들은 복잡계는 어떤 경우 단순계보다 교란에 순응적으로 더 잘 기능한다고 믿 는다. 환언하면, 복잡계는 단순계보다 스트레스와 변화에 더 잘 견딜 수 있는 능력을 지니고 있다는 것이다. ${ }^{2)}$ 그러 나 복잡계는 동시에 복잡한 동태성을 지니고 있기 때문 에, 일단 충격이 가해지면 그에 대한 물결효과가 광범위하 게 나타날 수 있다.

따라서 중요한 것은 (i) 생태계의 교란은 무한정 지속될 수 없으며, (ii) '어느 누구도 그 프로세스가 생태계의 통 합성을 임계수준(생명유지 기능이 상실되거나 붕괴되는 상황) 이하로 떨어뜨리지 않고 얼마나 오래 지속될 수 있 을지 모른다'는 사실을 이해하는 것이다. (iii) 또한 생태계 의 어떤 부분은 다른 부분들보다 중요하다는 점을 주목하 여야 한다. 인간의 생존에 있어서 머리가 신체의 다른 어 떤 부분보다 중요한 것처럼, 생태계는 그 생태계 내의 여 타 종들보다 통합성과 안정성에 결정적인 역할을 하는 종, 즉 종석 종(宗石 種, keystone species)에 크게 의존한 다는 사실이다. 따라서 종석 종은 생태계 변화의 바로미터 라고 할 수 있다.

\section{생물다양성과 녹색성장 \\ 생물다양성의 기능과 안정성}

생물학자 Wilson(1992)은 두 가지 환경문제의 중요성을 지적한다. 첫 번째는 공기 · 수질 오염, 성층권 오존파괴, 지구온난화와 같은 인간의 경제활동에 의해 야기된 총체 적 위협이고, 두 번째 문제는 생물의 다양성 손실이다. 후 자는 전자의 결과라고 할 수 있다. 전자는 가역적이지만, 후자의 경우에는 이미 멸종된 생물종을 복구할 수 있는

\footnotetext{
2) 1973 년 구소련의 생물학자 카므실로프는 자신이 만든 일련의 인공 생물계에 독성이 강한 페놀산을 첨가하는 통제된 상태에서의 실험을 수행하였다. 첫 번째 생태계는 단지 박테리아로 구성되었는데, 그 생물계의 멤버에 대해서만 변화가 주어졌고, 다른 생물 계 멤버들의 도움 없이 먹이 $\rightarrow$ 배설물 $\rightarrow$ 먹이의 과정을 재순환시킬 만큼 생화학적으로 완벽하게 기능하는 것이었다. 박테리아 는 스스로 페놀을 분해할 수 있었지만, 더 복잡한 생태계보다는 빨리 분해하지 못했다. 박테리아와 수생 식물(水生植物)을 가지고 있는 두 번째 생태계는 첫 번째 박테리아 생태계보다 빠른 속도로 페놀을 중화시킬 수 있었다. 이런 식으로 세 번째 생태계에는 연 체동물이 첨가되었는데 훨씬 더 효과적이었다. 네 번째 실험에서는 물고기, 연체동물, 수생 식물, 박테리아로 생태계가 구성되었 으며, 페놀을 가장 빠른 속도로 재순환하는 시스템은 단순히 복잡한 유기체의 집합체가 아니라 더욱 최근에 진화한 유기체를 원 시적 생물체와 혼합한 생물계였다는 것이다. 카므실로프의 실험은 생물의 다양성이 왜 가이아 가설에서 필수적인 조건인지를 분 명하게 보여주고 있다. 가이아는 어떤 특정 종(特定種)의 생태계 지배를 허용하지 않는다. 원생생물로부터 고등 동식물 그리고 인 간에 이르기까지 지구상의 모든 종(種)은 거대한 가이아의 한 부분을 형성하고 있을 따름이다. 인간의 자아실현 또한 자연과 밀접 한 관계를 가지고 있다. 맑고 푸른 바다와 그 속에서 힘차게 유영하는 물고기들을 볼 때 우리가 대자연에 대하여 갖는 경외심(京 外心) 속에서 바이오필리아의 존재를 확인할 수 있다. 인간 활동으로부터 나오는 모든 폐기물을 카므실로프의 페놀이라고 지칭하 고, 페놀량이 점점 증가하여 해양 생물들이 하나 둘 멸종하고 있다고 가정해 보자. 그러던 어느 날 해양 생태계가 자정 기능을 완 전히 상실함으로써 갑자기 가이아의 지구생체 조절 기능이 멈추었다고 상상해 보자. 이러한 상황에 직면해서야 비로소 우리의 존 재와 자아실현이 자연과 매우 밀접하게 연관되어 있다는 사실을 깨닫게 된다면, 자연과의 관계를 회복할 수 있는 기회는 극도로 제약받게 될 것이다(Kamshilov 1976; Sagan and Margulis 1993).
} 
방법과 그 멸종된 생물이 만들어낸 생태계 자체에 대한 것이 거의 알려져 있지 않다는 것이다.

생물다양성 손실은 왜 중요한 문제인가? 보다 나은 삶 을 위하여 인간은 길들이고 재배할 수 있는 동식물 같은 자연자원을 특화하여 집약적으로 생산해왔다. 이러한 특 화와 인간의 성취는 한 생태계 내의 많은 다른 생물종들 을 밀어내버렸다. 그러나 인구증가와 빈곤문제 같은 현상 을 고려하면, 생물다양성 손실의 불가피성은 어느 정도 인 정될 수도 있다. 그럼에도 불구하고 생물다양성이 지금과 같이 지속적이고 빠른 속도로 상실될 경우 그것은 분명히 우리 인간의 중대한 실수가 아닐 수 없다. 생태계 기능과 생물다양성 사이의 관계에 대하여 많은 부분이 알려져 있 지 않지만, 전자는 후자에 의존한다는 것이다. 생물다양성 손실은 최소한 특정 시기와 장소 그리고 지방-지역·글 로벌 차원에서 생태계 기능을 심각하게 손상시킬 수 있다 (Prugh et al. 1995).

이와 같은 제약조건은 현 세대에 만 적용되지 않으며, 지속 가능한 경제성장을 제약하지 않을 수 없다. 그렇다면 지속 가능한 발전과 지속적인 인간 복지 향상을 위한 유 용한 방법은 녹색성장 ${ }^{3)}$ 이라고 할 수 있으며, 생물다양성 을 포함한 자연자본의 스톡과 유량을 획기적으로 제고하 고 유지할 수 있어야 한다. 생물다양성과 생태계기능(희소 자원) 그리고 인간경제(무한한 욕망) 사이의 밀접한 연관 성을 고려하면, 생물다양성 손실의 위험성이 얼마나 클 수 있는지가 자명해진다. 생물다양성은 일반적으로 생물종의 다양성(즉, 생물종의 수와 분포 그리고 바이오매스)으로 인식된다.

그러나 생물다양성은 세 가지의 다른 중요한 특성을 지 니고 있다(Jansson and Jansson 1994). 첫째, 한 생태계 내 에서의 다른 종들의 생물학적 역할이 무엇인가를 의미하 는 소위 기능적 다양성이다(Table 1). 그것이 중요한 이유 는 생태계의 생산성과 안정성에 중요한 요소이기 때문이 며, 생태계의 생산성과 생물다양성 사이에는 비교적 높은 상관관계가 있는 것으로 알려져 있다.

현장연구들의 결과는 생물다양성이 감소하면 생태계가 제공하는 서비스의 질도 감소한다는 것을 보여준다. 스트 레스를 받은 생태계의 기록을 보면 그러한 현상은 예측할 수 없을 정도로 불확실하다는 사실을 알 수 있다. 또한 멸 종이 확산됨에 따라 손실된 생물종 중 어떤 것들은 종석 종이라는 사실이 밝혀졌다. 그런 종석 종의 멸종은 필연적 으로 다른 종을 감소시키며 생존 생물의 개체군들을 통해 물결효과를 유발한다. 종석 종의 손실은 마치 우발적으로 송전선을 파괴함으로써 전력공급을 중단시키는 천공기와
Table 1. Functions of the natural environment

\begin{tabular}{|c|c|}
\hline \multicolumn{2}{|r|}{ Regulation Functions } \\
\hline 1 & Protection against harmful cosmic influences \\
\hline 2 & Regulation of the local and global energy balance \\
\hline 3 & $\begin{array}{l}\text { Regulation of the chemical composition of the } \\
\text { atmosphere }\end{array}$ \\
\hline 4 & Regulation of the chemical composition of the oceans \\
\hline 5 & Regulation of the local and global climate \\
\hline 6 & $\begin{array}{l}\text { Regulation of runoff and flood prevention(watershed } \\
\text { protection) }\end{array}$ \\
\hline 7 & Water catchment and ground water recharge \\
\hline 8 & Prevention of soil erosion and sediment control \\
\hline 9 & Formation of topsoil and maintenance of soil fertility \\
\hline 10 & Fixation of solar energy and biomass production \\
\hline 11 & Storage and recycling of organic matter \\
\hline 12 & Storage and recycling of nutrients \\
\hline 13 & Storage and recycling of human waste \\
\hline 14 & Regulation of biological control mechanism \\
\hline 15 & Maintenance of migration and nursery habitats \\
\hline 16 & Maintenance of biological (and genetic) diversity \\
\hline \multicolumn{2}{|r|}{ Carrier Functions } \\
\hline & Human habitation and (indigenous) settlements \\
\hline & Cultivation (crop growing, animal husbandry, aquaculture) \\
\hline & Energy conversion \\
\hline & Recreation and tourism \\
\hline & Nature protection \\
\hline \multicolumn{2}{|r|}{$\begin{array}{l}\text { Production Functions } \\
\end{array}$} \\
\hline & Oxygen \\
\hline & Water (for drinking, irrigation, industry, etc.) \\
\hline & Food and nutritious drinks \\
\hline & Genetic resources \\
\hline & Medicinal resources \\
\hline & Raw materials for clothing and household fabrics \\
\hline & $\begin{array}{l}\text { Raw materials for building, construction and industrial } \\
\text { use }\end{array}$ \\
\hline 8 & Biochemicals (other than fuel and medicine) \\
\hline & Fuel and energy \\
\hline & Fodder and fertilizer \\
\hline
\end{tabular}

\begin{tabular}{ll}
\hline \multicolumn{1}{c}{ Information Functions } \\
\hline 1 & Aesthetic information \\
2 & Spiritual and religious information \\
3 & Historic information (heritage value) \\
4 & Cultural and artistic inspiration \\
5 & Scientific and educational information \\
\hline
\end{tabular}
Source: Prugh T et al. (1995), pp 57

\section{같다(Wilson 1992).}

생물다양성과 생태계 안정성 사이의 연관성은 더욱 복 잡하고 생태학자들 사이에 이견이 분분하다. 안정성에 대 하여 여러 가지 다른 정의가 있다(Holling 1973). 하나는

\footnotetext{
3)녹색성장은 지속 가능한 발전을 위한 유용한 수단으로서 생태계의 환경 부양능력을 고려하여 환경적으로 건강하고 경제적으로 수 익성이 보장되는 성장으로 정의할 수 있다.
} 
안정성은 곧 복원력(즉, 생태계가 교란되었을 때 복원능 력)을 의미한다. 어떤 생태학자들은 더 높은 생물다양성은 더 큰 복원력을 가진다고 주장한다. 한 생태계가 유사한 기능을 수행하는 다른 생물종을 수용할 때, 그 생태계는 하나 이상의 생물종이 없어지는 경우에도 다른 종들이 그 기능을 수행할 수 있기 때문에 여전히 원활하게 기능할 가능성이 높다는 것이다. 생물다양성이 낮은 생태계는 특 정 종이 개별적으로는 견고할지라도 중복성 또는 보완성 이 결여될 수 있고, 따라서 충격이나 교란에 취약할 수 있 다. 그러나 생물종의 누적 손실은 먹이망의 생산 효율성과 영양유량을 감소시키기 때문에 높은 생물다양성을 지닌 생태계일지라도 그 복원력에 심각한 제약을 가할 수 있 다. 생태계의 통합성과 안정성에 결정정인 역할을 하는 생물종, 즉 종석 종(keystone species)의 손실은 생태계의 붕괴를 초래할 수 있고 그것의 물리적 구조를 바꿀 수도 있다.

둘째, 일반적으로 안정성이 생물다양성을 유인한다. 즉, 아주 오래 동안 안정적인 생태계는 높은 다양성을 보일 수 있지만, 격심하고 광범위한 교란이 발생하면 당해 생태 계의 신속한 회복과 재생산이 이루어지기 어렵다는 것이 다. 그러나 충격이 오래 지속되지 않는 한, 창조적 파괴를 수반하는 주기적 자연 순환과정에서 생태계는 높은 회복 력과 강력한 자가 갱생력을 보이는 경향이 있다(Costanza et al. 1993).

셋째, 기능적 다양성 외에도 생태계는 시간적 공간적 다양성을 보인다. 시간적 다양성은 햇빛의 일간·계절적연간 변화에 영향을 받게 되는데, 이는 에너지와 물질 유 량의 시간적 변화에 따른 생태계의 변화를 의미한다. 공간 적 다양성은 한 생태계에서 개별적 역할을 맡은 다양한 생물들의 공간적 차이를 말한다. 예컨대, 개방된 해양에서 기초생산자들은 투광대에 서식하지만, 에너지 및 물질 유 량과 해수 탁도(濁度)의 시 - 공간적 변화에 따라 투광대 는 1미터에서 200미터까지 다양하다. 그러나 주 분해자 (major decomposers)들은 수 천 미터 수심에서 서식하며, 투광대와 비투광대는 분해된 유기물의 해저 침착, 해류의 용승작용 등에 의해 하나의 거대한 생태계로 연결되어 있다.

\section{저탄소 녹색 성장. 직 - 간접 편익}

생물다양성의 이러한 특징을 고려할 때, 어떻게 그것의 가치를 평가할 수 있을까? 이는 결코 용이한 일이 아니지 만, 생물다양성의 실질적이고 현실적인 중요성은 직 · 간 접 경제적 편익으로 설명될 수 있다. 직접편익은 상대적으 로 분명하다: 식품, 제품, 약재, 유전자 은행 등을 들 수 있
다. 직접적인 경제적 편익이 제품과 같은 것이라면, 간접 편익은 하부구조와 같다(Ehrlich and Ehrlich 1991). 경제 적 간접편익에는 해양-육상식물의 탄소동화작용, 대기가 스 조절, 기후·해수 조절, 토양 형성과 유지, 해충의 통 제, 식물의 수분작용 등이 포함될 수 있고, 이들 간접편익 요인들은 직접편익에 광범위한 영향을 미친다.

예컨대, 사회간접자본으로 정의되는 항만, 공항, 철도 등 하부구조는 그 자체가 상품을 생산하지는 않지만, 상품 및 서비스의 생산과 유통을 위해 필수불가결한 것이다. 이 런 관점에 볼 때, 자연환경과 생태계를 포함하는 자연자본 은 인간에게 필요한 모든 재화와 서비스를 생산하는데 없 어서는 안 될 최상위 간접자본이다. 이는 두 가지 자본, 즉 자연자본과 인공자본을 상정한 생산 확장선 및 등생산량 곡선으로 설명될 수 있다.

Fig. 2에서 보는 바와 같이 지금의 경제가 자연자본을 과도 이용하는 점 $\mathrm{A}$ 에 있다면, 녹색성장정책은 현재의 경 제, $\mathrm{A}$ 를 점 $\mathrm{B}$ 로 이동시키고자 하는 것이다. 환언하면, 자 연자본의 지속성을 회복 - 유지하면서, 자연과 인간의 조 화를 도모하는 성장정책인 것이다. 우리가 자연자본을 과 도하게 이용하는 성장 패러다임을 시정함으로써 녹색자본 기반의 균형성장에 필수적인 자연자본을 회복시켜나간다 면, 자연자본의 과도 이용에 기반을 둔 성장의 한계를 극 복하면서 성장을 최소한 현재 수준으로 유지할 수 있고, 현 세대와 미래 세대의 복지를 지속적으로 증대시킬 수 있을 것이다.

예컨대, 저탄소 - 녹색성장 정책은 탄산가스 등 온실가 스를 감축시킴으로써 장기적으로 기후변화 및 지구온난화 에 의한 대형 기상이변(예: 초대형 태풍, 폭우, 폭설, 폭염 등)의 발생확률과 그에 따른 막대한 인명·재산 피해를 줄 일 수 있다. 즉, 하향성 위험(down-side risk) ${ }^{4)}$ 을 감소하는

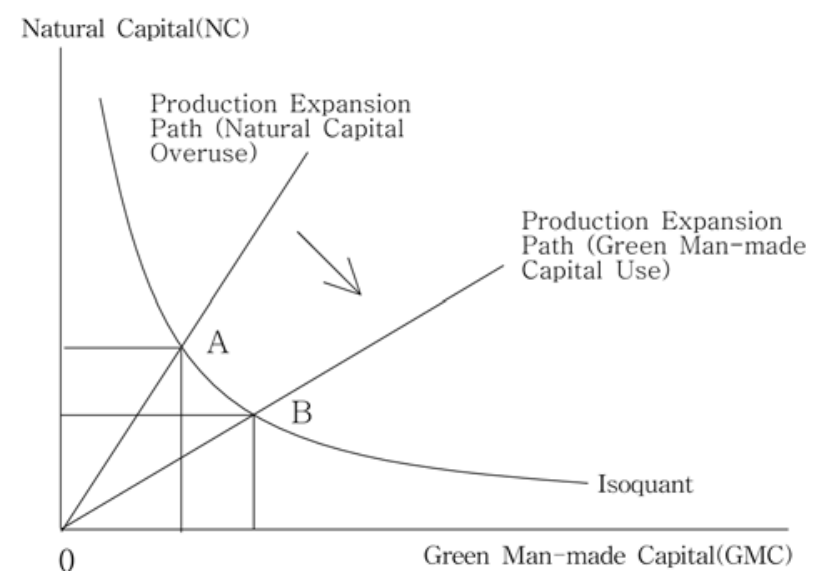

Fig. 2. Green capital-based development.

4)하향성 위험이란 어떤 사건의 발생확률은 매우 낮지만, 일단 발생하면 그 피해가 상상을 초월할 정도로 큰 경우를 말한다. 


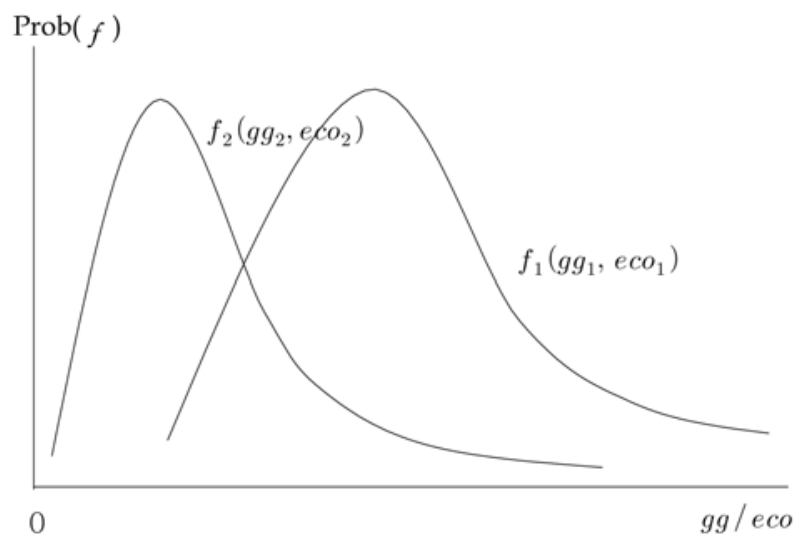

Fig. 3. Low carbon-green development and change in downside risk.

데 기여할 수 있다. 온실가스 배출량을 $g g$, 생태계 복원률 을 $e c o$, 확률분포를 $f$ 로 정의하고, $g g_{2} \leq g g_{1}, e c O_{2} \geq e c O_{1}, f_{2}$ $\leq f_{1}$ 라고 가정하면 ${ }^{5)}$, Fig. 3에서 보듯이 온실가스를 감축 하고 생태계를 복원할 경우, 하향성 위험 확률분포는 왼쪽 으로 이동하게 되고, 그 결과 피해의 기대 값이 크게 낮아 질 수 있다.

특히 수산업, 농업 등 1 차 산업은 자연력에 크게 의존하 는 산업이기 때문에 초대형 태풍, 극심한 가뭄, 폭염, 폭설 등 하향성 위험에 노출될 확률이 높고, 그런 대형 자연재 해가 발생하면 어가나 농가는 흔히 재생산 능력을 상실하 게 된다. 그럴 경우, 국가는 막대한 비용을 투입함으로써 피해를 복구해야만 한다. 설령 통상적인 피해 복구가 이루 어진다고 해도, 이미 영구히 손실된 인명 피해와 생태계는 금전으로 환산하기가 극히 어렵다. 하향성 위험에 대한 막 대한 기회비용을 고려할 때, 저탄소·녹색성장 정책으로 의 전환은 필연적 선택이다.

\section{4. 저탄소 • 녹색성장정책 패러다임}

\section{국가}

녹색성장의 개념과 전략은 로키산 연구소(Rocky Mountain Institute $)^{6)}$ 의 연구보고서『녹색 성장: 생태와 부 동산 개발의 통합(Green Development: Integrating Ecology and Real Estate)』에서 유래한다. 녹색성장은 공 동체 또는 지역 개발과의 연계성을 포함하는 토지 이용 계획으로, 현장 특유의 녹색 건물 ${ }^{7)}$ 의 개념과 밀접한 관련 이 있다. 이는 도시 계획, 환경 계획, 건축, 공동체 건물 등 을 포함한다. 이는 과거 30 여 년 동안 논의되어온 지속가 능한 개발 철학과 맥을 같이 하는 개념이지만, 보다 정책행동 지향적 개념이라고 할 수 있다.

세계는 지금 기후변화로 상징되는 '환경 위기'와 '자원 위기'라는 양면위기에 직면해 있다. 특히 기후변화는 빈번 한 대형 기상재해를 유발하고 생태계의 질서를 근본적으 로 뒤흔들면서 인류의 생존과 발전을 위협하고 있다. 지금 과 같이 에너지 다소비 체제가 지속될 경우 지구촌이 지 불해야 할 기후변화에 따른 경제적 손실은 매년 세계 $\mathrm{GDP}$ 의 5 20\%에 달할 것으로 추정되고 있다(Stern Review 2006). ${ }^{8)}$ 여기에 신흥 개발도상국의 경제개발과 세계인구 의 지속적인 증가는 에너지·자원 부족 현상과 이에 따른 가격상승을 가속화하고 있다.

선진국들은 이미 자원 효율적·환경 친화적 이용에 국 력을 집중하고 있다. 녹색산업, 녹색기술이 새로운 경제성 장 엔진으로 자리잡아가는 것도 같은 맥락이다. 기존의 '요소 투입형' 성장방식은 환경을 해칠 뿐만 아니라 경제 적 한계를 보이고 있다. 자원과 에너지 가격이 급상승하면 서 이들의 대량투입에 의존하는 경제시스템은 지속 가능 할 수 없게 된 것이다. EU 등 선진국들은 녹색기술 육성

\footnotetext{
5)온실가스 배출량 $(g g)$ 과 생태계 복원률 $(e c o)$ 은 저탄소·녹색성장 정책의 수행 여부에 따라 변화하게 되며, $g g$ 과 $e c 0_{1}$ 은 저탄소·녹 색성장 정책이 수행되지 않는 경우 온실가스 배출량과 생태계 복원률을 나타내며, $g g_{2}$ 와 eco는 저탄소·녹색성장 정책이 수행될 경우를 의미한다.

${ }^{6}$ Wilson et al. (1998)

7)그린 빌딩 (green building) 또는 녹색 건물은 건물의 에너지, 물, 자재 등의 자원에 대한 사용의 효율성 제고를 실행하는 것으로, 동 시에 건물의 사용 기간에 인간의 건강과 환경에 미치는 영향을 최소화할 수 있도록 설계, 건설, 운용, 보수 관리, 철거한다. 그린 빌 딩은 건축된 환경이 인간의 건강과 자연 환경에 전체적으로 주는 영향을 줄이도록 다음과 같이 설계된다. (i) 에너지를 비롯한 자 원의 효율적인 사용, (ii) 주민의 건강을 보호하고 종업원의 생산성 향상, (iii) 폐기물과 공해, 환경적인 퇴보 완화. 유사한 개념으로 자연 건축(natural building)이 있는데, 이는 소규모로 지역적으로 활용 가능한 자연 자원의 이용에 중점을 두는 것을 말하며, 또한 지속 가능한 설계와 녹색 설계라는 용어도 쓰인다. 지속가능한 개발과 지속가능성과 관련된 개념은 그린 빌딩에는 없어서는 안 될 요소이다. 효율적인 그린 빌딩은 (i) 보다 적은 에너지와 물을 사용하여 생산성을 높이고 결과적으로 운용비용을 절감하여야 하고, (ii) 실내의 공기의 질을 개선하여 공중과 주민의 건강을 개선하여야 하며, (iii) 환경에의 영향을 줄여야 한다. 예컨대, 이는 빗물의 유 출과 열섬효과를 줄이는 것이다. 그린 빌딩을 실천하는 이들은, 지속가능한 건물의 외관과 풍채가 반드시 일반적인 건물들과 구별 될 필요가 없음에도 종종 생태적일 뿐만 아니라 건물 구조와 주변의 자연 경관, 인공으로 조성된 환경과의 심미적인 조화를 이루 기도 한다.

8)기후변화가 경제에 미치는 영향에 관한 Stern Review는 700페이지에 달하는 보고서이며, 2006년 10월 30일 영국정부를 위하여 집 필되었다. 이는 기후변화에 관한 첫 경제 보고서는 아니지만, 가장 널리 논의 · 인용되고 있다.
} 


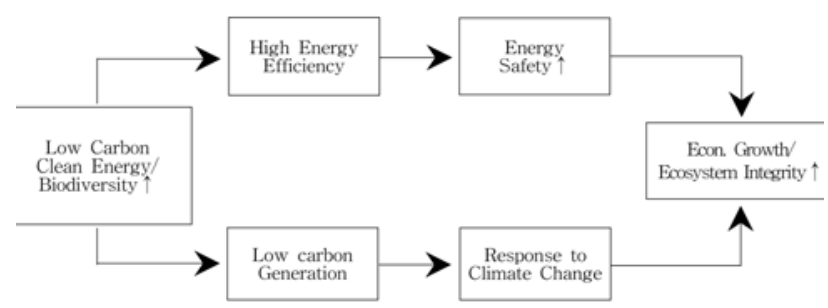

Fig. 4. Low carbon · green development paradigm.

과 환경규제를 통해 관련 산업의 성장을 유인함은 물론, 새로운 시장을 선점하고, 동시에 일자리를 창출하는 등 빠 른 대응행동을 보이고 있다. 특히 자동차 분야의 경우 이 미 하이브리드차, 전기차, 수소차 등 저탄소 차량 제작을 위한 치열한 경쟁을 벌이고 있다.

우리나라는 세계 10 대 에너지소비국이다. 그런데 이 에 너지의 $97 \%$ 를 해외수입에 의존하고 있으며, 향후 온실가 스 감축 의무가 부과될 경우, 우리나라 경제가 안게 될 부 담은 상상을 초월할 수 있다. 기후변화 문제가 심각해질수 록 국제사회는 점차 강력한 규제를 통해 각국의 탄소배출 량 감축을 강제할 것이다. 최근 정부가 ‘저탄소 녹색성장' 을 향후 60 년의 새로운 국가비전으로 제시한 것도 이런 세계적 추세 변화에 대비한 선제전략이라고 하겠다(Fig. 4). ${ }^{9)}$ 왜냐하면, '저탄소 - 친환경 또는 녹색성장 패러다임' 이 새로운 성장을 이끌어낼 전략이라는 인식이 전 세계 적으로 확산되는 상황에서, 이런 흐름을 선도해나가지 않고서는 일류 선진국가로 진입하기가 사실상 어렵기 때 문이다.

녹색성장(green growth)이라는 단어는 환경(natural environment)과 성장(economic growth)이라는 두 가지 가 치를 동시에 포괄한다. 이는 비전적 이미지를 가진 실천적 단어의 조합이지만 이상적인 개념으로 들릴 수도 있다.
환경(전체)과 성장(부분)이라는 잘 어울릴 것 같지 않은 두 개념의 결합은 이미 선진국에서는 새로운 성장철학으 로 자리 잡아가고 있다. 기존의 경제성장 패러다임을 환경 친화적으로 전환하는 과정에서 신에너지·친환경 관련 기 술과 산업으로부터 미래 유망 상품과 신기술이 개발되고 기존 산업과 상호 융합함으로써, 새로운 성장 동력과 새로 운 일자리를 창출할 수 있을 것으로 보인다(Table 2). ${ }^{10)}$

녹색성장의 핵심은 경제성장을 추구하되 자원이용과 환 경오염 및 파괴를 최소화하고, 이를 다시 경제성장의 동력 으로 활용하는 '선순환구조'에 있다. 예컨대, 석유를 대체 하고 배출을 줄이기 위해 하이브리드 선박엔진을 개발 생산하고 해양생물다양성을 제고함으로써 경제성장을 일 궈낸다면 이는 녹색성장이 구현된 수산업의 모습이다. 결 국 정부가 추진하려는 ‘녹색성장'은 환경보전과 경제성장 이라는 두 가지 가치의 시너지효과를 극대화하려는 것이 다. 이는 정부와 국민, 기업과 시민사회가 공유된 비전을 바탕으로 창의적으로 발전시켜 나가야 할 중차대한 과제 이기도 하다

\section{수산부문}

수산부문은 농업 - 임업부문과 더불어 자연자본에 크게 의존하는 산업부문이다. 환언하면 수산부문은 해양환경과 해양생물의 이용·관리를 통해 국가 녹색성장정책에 기여 할 수 있는 큰 잠재력을 지니고 있음을 의미한다. 해양자 연자본(예: 해양, 해양생물자원, 해양생물다양성 등)의 실 질적 중요성은 직·간접 경제적 편익으로 설명될 수 있 다. 직접 편익은 식품, 제품, 약재, 유전자은행 등이다. 직 접적인 경제적 편익이 제품과 같은 것이라면, 간접 경제적 편익은 하부구조와 같다. 간접적인 경제적 편익에는 해양 식물의 탄소동화작용, 대기가스 조절, 기후·해수 조절 등

Table 2. Three key elements and contents of green development

\begin{tabular}{cl}
\hline \multicolumn{1}{c}{ Three Key Elements } & \multicolumn{1}{c}{ Contents } \\
\hline $\begin{array}{c}\text { Healthy growth but minimizing the use } \\
\text { of energy and resources }\end{array}$ & $\bigcirc$ Transformation the existing industries into low energy structure \\
& $\bigcirc$ Efficient use and consumption of energy \\
& $\bigcirc$ Improving ecosystem efficiency \\
\hline \multirow{3}{*}{$\begin{array}{c}\text { Minimizing carbon emission at the } \\
\text { same level of energy and resources }\end{array}$} & $\bigcirc$ Development of clean energy such as atomic energy \\
& $\bigcirc$ Establishment of low carbon/environmentally friendly Infra-structure \\
& $\bigcirc$ Facilitating of consumer's purchase of green goods and services \\
\hline \multirow{2}{*}{$\begin{array}{c}\text { Development as a new growth driving } \\
\text { force }\end{array}$} & $\bigcirc$ Investment in green technology R\&D \\
& $\bigcirc$ Rearing new renewable energy industry as a green and export industry \\
& $\bigcirc$ Assisting the world market exploring \\
\hline
\end{tabular}

\footnotetext{
${ }^{9} \mathrm{http} / /$ korea.kr/newsWeb/pages/special/green/greenSection/what.jsp 참조.

${ }^{10)}$ 위의 웹사이트 참조.
} 
이 포함될 수 있고, 이들 간접편익 요인들은 직접편익에 광범위한 영향을 미친다.

수산부문 녹색성장정책은 경제성과 환경성이 통합된 개 념으로 사람(people), 지구해양환경(planet ocean), 이윤 (profit)이라는 $3 \mathrm{P}$ 의 관점에서 접근할 수 있다. 첫째, 수산 부문 녹색성장 정책 추진과 관련된 생산자 - 소비자 - 정 책담당자 - 연구자 - 관련단체 - 언론 사이에 적절하게 역 할을 분담하고 그들 간 협력체제를 구축하는 것이 중요하 다. 둘째, 해수 - 해저 - 해양생물 - 사람 등 해양생태계를 직·간접으로 구성하는 해양환경요소에 대해 환경용량 범 위에서 지속적으로 관리하고 환경의 질을 유지해야 한다. 셋째, 수산업이 해양생명산업으로서 지속적으로 발전·유 지기 위해서는 녹색경영능력을 배양하고, 녹색기술을 혁 신하고, 정책적으로 적극 지원함으로써 지속성과 경쟁력 을 제고 · 유지해야 한다. ${ }^{11)}$

수산부문의 녹색성장은 해역별 또는 한반도 전 해역의 환경용량과 생물자원 부양능력을 고려하여 잡는 어업과 양식어업 방식을 환경친화적으로 전환하고, 저탄소·저오 염을 지향하는 기술개발, 녹색어촌개발 등을 통한 수산부 문 저탄소 - 녹색성장을 의미한다(Fig. 5). 기존의 수산업

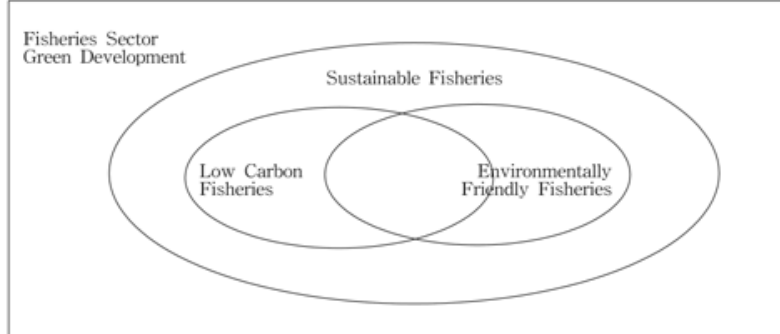

Fig. 5. Position of low carbon · green fisheries.
성장 패러다임에서 저탄소·녹색성장 패러다임으로 전환 하기 위해서는 명확한 비전과 정책목표가 설정되어야 한 다. 비전(vision)은 수산업과 해양환경의 조화를 통해 온실 가스를 완화하고 해양생태환경을 개선·보전함으로써 지 구온난화 문제 해결에 기여하고, 현 세 대와 미래 세 대를 포함한 국민의 복지를 지속적으로 향상하는 것이다. 정책 목표에는 해양환경 관리와 어업관리를 통한 온실가스 완 화(흡수·감축), 해양생태계 보전, 수산물 안전성 확보, 어 업 수익성 제고, 녹색어촌(관광)개발 등이 포함될 수 있으 며, 이에 대한 계량적 지표를 설정할 필요가 있다(Fig. 6).

수산부문의 저탄소·녹색성장을 추진하기 위한 전략수 립의 기본방향은 첫째, 감축(reduction)↔재활용(recycle) $\leftrightarrow$ 재사용(reuse)↔재생산(renewal)의 $4 \mathrm{R}$ 을 토대로 자원순 환형 녹색수산업을 정착시키도록 해야 한다. 둘째, 수산물 의 생산 극대화에서 적정 생산으로 전환해야 한다. 생산성 극대화를 통한 생산증대 중심에서 지역 수산 - 해양 환경 과 온실가스 배출·흡수 여건 등을 고려하여 적정생산 체 제로 전환해야 한다. 셋째, 수산부문은 온실가스의 배출완 화와 해양환경의 질적 개선 그리고 어업방법 전환 등을 위해 지원 · 규제·조정 등 정책의 적절한 선택과 결합이 이루어져야 한다. 넷째, 공유자원 이용에 있어 불법행위와 도덕적 해이를 완화하기 위한 강력한 $\mathrm{MCS}$ 시스템이 구 축되어야 한다. 다섯째, 저탄소-녹색성장을 추진함에 있 어 충분한 정보제공과 체계적 교육·홍보 등을 통해 저탄 소·녹색성장에 대한 관련주체의 인식을 제고하고 공감대 형성과 적절한 역할분담이 이루어져야 할 것이다.

\section{5. 결론 및 정책함의}

21세기의 가장 중요한 담론은 분명히 '인간과 환경의

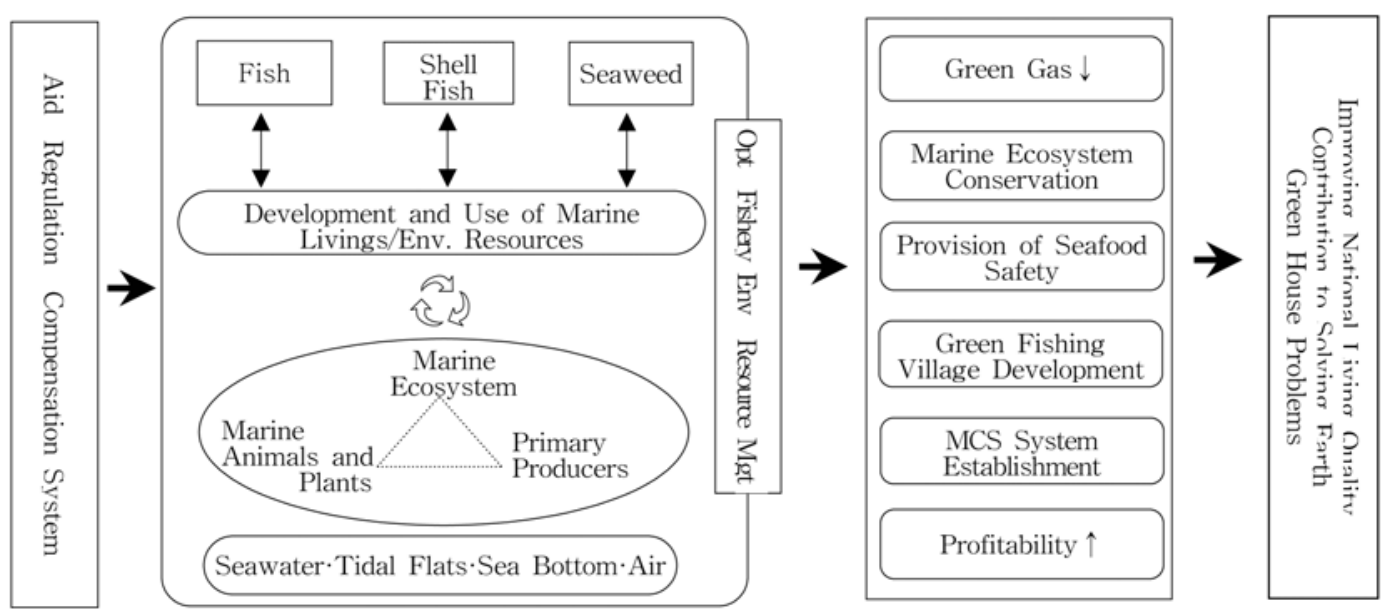

Fig. 6. Vision and goals of fisheries' low carbon · green development.

11)김창길, 정학균 (2009) 농업부문 녹색성장 심포지엄 자료집 D250. 한국농촌경제연구원, pp 42(Fig. 6 참조 및 재구성) 
화해'이다. 과학과 기술의 만남은 순식간에 우리가 살고 있는 문명의 모습을 통째로 바꾸어 놓았다. 자연환경 또는 자연자본의 과도한 이용 대가로 얻은 오늘의 찬란한 물질 문명의 발전은 육지와 바다 그리고 우주 개발에서 눈부신 발전을 가져왔다. 특히 과학기술의 진보는 우리의 과학적 사유 영역을 놀라울 정도로 크게 넓혀주었다. 보이지 않던 것이 보이게 되었고, 개발의 영역이 아니던 것이 개발될 수 있게 되고, 인간사유의 대상조차 아니었던 것들이 사유 의 영역 안으로 들어왔다. 공상이 현실로 변모해가고 있는 것이다.

그러나 그 이면에 드리워진 어두운 그림자, 즉 자연환 경의 파괴 문제는 자연자본을 과도하게 이용해온 기존의 발전방식에 수정을 요청하기에 이르렀다. 환언하면 자연 환경의 복원과 천문학적인 비용지출을 불가피하게 한 것 이다. 기존의 발전방식을 수정하는 데는 먼저 인식의 전 환과 새로운 패러다임이 요구된다. 그 인식의 전환은 나 무와 숲, 미시적인 것과 거시적인 것, 현 세대와 미래 세 대 간의 딜레마 극복을 위한 새로운 철학적 인식을 의미 한다. 새로운 패러다임이란 과학기술 개발과 질서를 기존 과학기술과 융합적이며, 보다 자연환경 순응적으로 전환 하는 것이다.

최근 정부는 저탄소·녹색성장이라는 새로운 패러다임 을 제시하였다. 이는 매우 중요한 새로운 비전이며, 디지 털시대 또는 롱테일(long tail) 경제 하에서 실용주의적인 새로운 시장 - 행동 지향전략이라고 할 수 있다. 이제 중 요한 것은 국가 녹색성장 패러다임과 3 대 요소 및 내용을 토대로, 부문별 녹색성장 비전과 목표와 전략을 수립하는 것이다. 이런 관점에서 볼 때, 수산부문은 온실가스 감축, 해양생태환경 보전, 수산식품 안정성 확보, 녹색어촌개발, $\mathrm{MCS}$ 시스템 구축, 수익성 향상 등을 통해 지구온난화 문 제 해결에 기여하고 국민 복지를 지속적으로 향상시킬 수 있는 비전적이고 실천적이며 수용성이 높은 전략을 수립 하여야 할 것이다.

인식의 전환과 새로운 과학기술개발 패러다임이 저탄 소·녹색성장정책의 핵심이지만, 새로운 패러다임은 기존 의 패러다임에 비해 공익이 더 강조되는 패러다임이라는 사실을 인식할 필요가 있다. 따라서 저탄소 - 녹색성장정 책에 있어서는 국가의 구상과 지원·규제·보상(initiative, aid, regulation and compensation: IARC) 시스템이 매우 중요하다. 최근의 미국 경제 문제가 보여주듯이, 자유 시 장경제 체제 하에서의 IARC 시스템은 일반적으로 광범위 하고 구조적인 도덕적 해이와 그에 따른 막대한 사회적 비용을 초래할 수 있는 가능성이 상존하기 때문에 집행력 이 높은 $\mathrm{MCS}$ 시스템 구축이 필수적이다.

수산부문은 어느 산업부문 보다 저탄소 - 녹색성장 잠 재력이 크고, 저탄소·녹색성장 정책이 가장 적절하게 적
용될 수 있는 산업부문이다. 예컨대, 해양 자체와 식물성 플랑크톤 그리고 해조류는 탄소 흡수 능력이 매우 크고, 8 만 척 이상에 달하는 연근해·원양 어선의 막대한 기름 사 용량을 획기적으로 감축할 수 있는 기름 절약형 기술개발 잠재력도 높다. 그 외에도 3 면의 연안에 산재해 있는 어촌 지역을 녹색개발 방식(예: 독일의 연안지역 개발방식 등) 으로 개발할 경우, 연안지역의 녹색 - 생태관광을 획기적 으로 발전시킬 수 있을 것이다.

자연의 일부인 해양 자연자본은 스스로 그러하고 당사 자 권리도 없다. 그렇다면 누가 녹색성장의 주체인가? 두 말할 필요 없이 사람이며, 특히 수산업에 직-간접으로 종 사하는 사람들이다. 수산부문의 저탄소·녹색성장 혁명은 바다와 물고기에 의해서 이루어지는 것이 아니라, 그 사람 들에 의하여 이루어지기 때문에 '욕망을 절제할 수 있는 욕망'에 의해 '자생적이며 능동적인 질서'가 확대될 때 비 로소 저탄소·녹색성장은 본 궤도에 오를 수 있게 될 것 이다. 그것이 가능하기 위해서는 수산부문 경제주체들의 옥망 절제를 촉진하고 자생적 질서를 능동적으로 창출하 는데 기여할 수 있는 강력한 IARC와 MCS 체제가 보완 적으로 구축되어야 할 것이다.

\section{사 사}

본 논문을 수정하고 보완하는 데 유익한 의견은 주신 한국해양수산개발원 장홍석 박사, 조정희 박사, 한국수산 회 이광남 박사 그리고 익명의 심사 위원에게 깊은 감사 를 드리고, 본 논문의 편집 - 게재과정을 관리하는 데 애 써주신 편집간사에게도 심심한 사의를 표합니다.

\section{참고문헌}

김용옥 (1999) 도올 김용이 말하는 노자와 21세기(상). 통나 무, 서울

앤더슨 크리스 (2006) 롱테일 경제학. 이노무브그룹 (역) 랜 덤하우스, 서울, $416 \mathrm{p}$

한국공해문제연구소 (1986) 한국의 공해지도. 일월각, 서울, $276 \mathrm{p}$

화이트헤드 알프레드 노드 (2000) 이성의 기능. 김용옥 (역) 통나무, 서울, $358 \mathrm{p}$

Berkes F, Folk C (1994) Investing in cultural capital for sustainable use of natural capital. In: Jansson A, Hammer M, Folke C, Costanza R (eds) Investing in Natural Capital: the ecological economics approach to sustainability. Island Press, Washington DC, pp 87-90

Carson RL (1962) Silent spring. Houghton Mifflin Company, New York, $368 \mathrm{p}$

Costanza R, Daley HE (1992) Natural capital and 
sustainable development. Conserv Biol, 6(1):37-46

Costanza R, Kemp W, Boynton W (1993) Predictability, scale and biodiversity in coastal and estuarine ecosystems: implications for management. Ambio, 22:8896

Daly HE (1991) Elements of environmental macroeconomics. In: Costanza R (ed) Ecological economics: the science and management of sustainability. Columbia University Press, New York, pp 125-128

Ehrlich P, Ehrlich A (1991) The value of biodiversity (unpublished manuscript).

Hayek FA (1973) Law, legislation, and liberty: a new statement of the liberal principles of justice and political economy, vol 1: rules and order. University of Chicago Press, $184 \mathrm{p}$

Holling DS (1973) Resilience and stability of ecological systems. Ann Rev Ecol Syst 4:1-23

Jansson A, Jansson B (1994) Ecosystem rroperties as basis for sustainability. In: Jansson A, Hammer M, Folke C, Costanza $\mathrm{R}$ (eds) Investing in natural capital: the ecological economics approach to sustainability. Island
Press, Washington DC, pp 21-26

Kamshilov MM (1976) Evolution of the biosphere. Mir Publishers, Moscow

Prugh T, Costanza R, Cumberland JH, Daly H, Goodland R, Norgaard RB (1995) Natural capital and human economic survival. International Society for Ecological Economics, Solomons, $198 \mathrm{p}$

Sagan D, Margulis L (1993) God, gaia and biophilia. In: Kellert SR, Wilson EO (eds) The biophilia hypothesis. Island Press, Washington DC, pp 345-364

Stone CD (1972) Should trees have standing? Oceana Publication, Dobbs Ferry, NY

Wilson A, Jenifer L, Uncapher L, McManigal L, Hunter L, Maureen C, Browning WD (1998) Green development: integrating ecology and real estate. Wiley, New York, $522 \mathrm{p}$

Wilson EO (1992) The diversity of life. Belknap Press of Harvard University Press, Cambridge, MA, pp 348

Received Feb. 25, 2009

Accepted Mar. 6, 2009 